\title{
The Relationship between Workforce Sustainability, Stress, and Career Decision: A Study of Kindergarten Teachers during the COVID-19 Pandemic
}

\author{
Luis Miguel Dos Santos
}

Endicott College, Woosong University, Daejeon 34514, Korea; luismigueldossantos@yahoo.com

\begin{abstract}
A shortage of qualified teachers has been a long-term problem in many school districts and education systems internationally. During the COVID-19 pandemic, the current human resource gap in teaching significantly impacted the quality of teaching services and the experience of all school parties. Based on social cognitive career and motivation theory, two research questions guided this study: (1) Why did kindergarten teachers decide to leave their teaching positions and education professions permanently during the COVID-19 pandemic? (2) Did stress, burnout, and technology-related issues influence their career decision? 60 kindergarten teachers shared their insights through interviews and focus group activities. The results indicated that personal considerations of their family and trained skills, surrounding environment and individuals, and financial considerations played important roles in their career decisions and sources of stress. The study provides recommendations to government heads, school leaders, human resource planners, and headteachers to replan and reform current human resource and workforce planning for the ongoing teachers' shortages during and after the COVID-19 pandemic.
\end{abstract}

Citation: Dos Santos, L.M. The Relationship between Workforce Sustainability, Stress, and Career Decision: A Study of Kindergarten Teachers during the COVID-19 Pandemic. Sustainability 2021, 13, 11521. https://doi.org/10.3390/ su132011521

Academic Editors: Peter Holland and Renee Paulet

Received: 17 September 2021

Accepted: 18 October 2021

Published: 18 October 2021

Publisher's Note: MDPI stays neutral with regard to jurisdictional claims in published maps and institutional affiliations.

Keywords: burnout; career decision; human resource management; stress; sustainable human resource management; teacher professional development; teacher shortage; teacher workforce

\section{Introduction}

Education is an essential foundation of all countries and regions as children are the future of their communities. Teachers and education staff are the professionals who deliver the curriculum and instruction to those children. Although kindergarten and elementary schools are the primary-level institutions where students receive their educational experiences at the basic level, parents and government leaders pay special attention in order to ensure positive teaching and learning experiences [1,2]. Work-related stress is not uncommon in many industries and professions, and particularly so in the field of education and teaching [3]. Teachers are required to manage heavy responsibilities, arrange and grade assignments, exercise classroom management, as well as overseeing administrative duties, such as Parents' Day and completing government documents. Moreover, regardless of the economic and financial situation, school districts and communities often face budget cuts and limitations in school resources [4]. Due to restrictions such as a shortage of human resources, teachers continue to face hardships, particularly during the COVID-19 pandemic.

According to a recent report from the Association of California School Administrators [5], about $8 \%$ of teachers leave the education profession each year, whilst $16 \%$ of teachers switch to another school for the following academic year. Although a reasonable turnover of teachers and their retirement should not impact academic and administrative development, a high turnover may impact students' academic experiences and achievements [6].

The COVID-19 pandemic has significantly impacted human resource planning in the American school system. A recent report [7] indicated that teachers, regardless of their years of experience, plan to leave their position after the 2020/2021 academic year. Many of these teachers felt that the government had forced them to return to school for 
face-to-face lessons. Despite many teachers' health concerns, the school districts and government agencies had continued with their plans without consulting the teachers' union. The government's face-to-face teaching policies made some teachers reconsider their career development as many, particularly the male teachers, were the breadwinners of their families. Although there are no government statistics about the turnover rate or human resource data from government agencies, many school districts have had to hire unqualified, substitute, and inexperienced teachers to fill the human resource gap during the 2021/2022 academic year [8].

A recent report [9] indicated that about $44 \%$ of teachers had decided voluntarily to leave their teaching position during the COVID-19 pandemic. A further report [10] showed the COVID-19 pandemic to have significantly changed human resource planning in many public-school districts in the United States. The issues raised were as follows: Firstly, of the almost 1000 teachers who completed the surveys, 43\% said stress and disappointment in their teaching positions had caused them to leave, whilst $24 \%$ felt their salary could not cover their mental and physical health requirements. Many teachers under the age of 40 decided to switch to other professions and industries as their teaching career had given them essential training and management experience useful in other industries in the market [8].

Secondly, the risk of working in a large and closed classroom environment was one of the biggest concerns, particularly as children were not eligible for vaccines under government policy. Teachers considered themselves to be exposed to a dangerous working environment within a group of unvaccinated people [11].

Thirdly, many teachers were not ready for the new online teaching and learning approach. Although school districts provided emergency training and technology support (in hardware and software), teachers unused to this felt burnt out as their contracts had not previously required them to use extensive technology. For example, in some subjects such as music, fine arts, and vocational courses, a virtual-based classroom environment would need additional preparation and requirements due to the new instructional style. As many of the teachers do not understand the delivery options, burnout could eventually lead them to new career decisions. A recent study [12] examined a group of language teachers' stress and coping strategies linked to the online teaching and learning environment of the COVID19 pandemic. The results indicated that workload, family health, loss of control at work, no recreation, and blurred lines were the top five sources of stress. A further study [13] gave time management, technology issues, parents, balancing home and teaching, and a lack of resources as the main concerns of online teaching during the COVID-19 pandemic.

The COVID-19 pandemic continues to impact school management and human resource management in the American education system and school districts. However, as this is a contemporary issue, there are only a few studies and academic research projects concerning this subject. Therefore, the results of this study will fill the research gaps in human resource shortages, school management during the global crisis, and long-term and sustainable solutions in teacher career development and decisions.

A shortage of qualified teachers has been a long-term problem in many school districts and education systems internationally. Many leaders want to understand how to establish sustainable human resources management and workforce development of their teachers and educational staff. During the COVID-19 pandemic, the current human resource gap in teaching significantly impacted the quality of teaching services and the experience of all school parties. As a result, the researcher employed the qualitative research method with multiple interview sessions, focus group activities, and member checking interview sessions from 60 former kindergarten teachers in the United States for the investigation. Based on social cognitive career and motivation theory [14-16], two research questions guided this study:

1. Why did kindergarten teachers decide to leave their teaching positions and education profession permanently during the COVID-19 pandemic?

2. Did stress, burnout, and technology-related issues influence their career decision? 


\section{Theoretical Framework}

Social cognitive career and motivation theory [14-16] was employed as the theoretical framework to explore and understand the relationship between stress and the career decisions of kindergarten teachers in the United States, based on the guidelines from the social cognitive career theory [16] and self-efficacy approach [17]. The social cognitive career and motivation theory was appropriate for understanding the internal and external factors which may influence an individual's motivations and decision-making process. First, the psychological and internal factors involved with self-efficacy impact the (1) academic interests, (2) personal considerations, and (3) achievements of education and career goals. Second, the social external factors impact the (1) interests in career development, (2) financial considerations, and (3) surrounding environments and individuals [14-16]. Figure 1 outlines the social cognitive career and motivation theory.

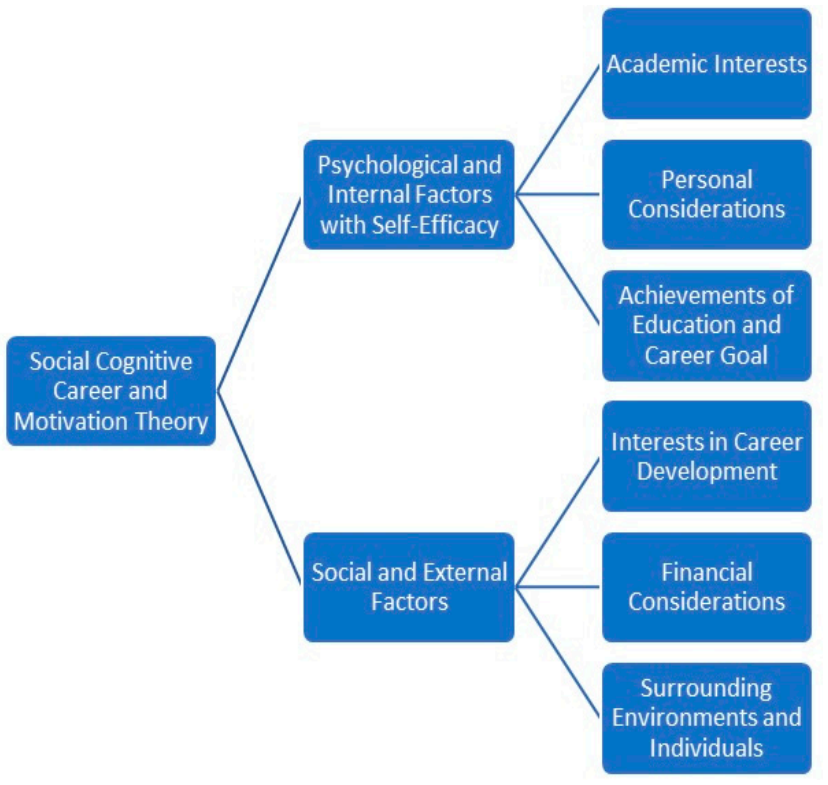

Figure 1. Social cognitive career and motivation theory [14-16].

Based on the application of the social cognitive career and motivation theory, the researcher could design the research questions, interview questions, and focus group questions to gather and collect qualitative data and stories from a group of kindergarten teachers. The social cognitive career and motivation theory was useful because it may direct social science researchers and scholars about the internal and external factors impacting individuals' behaviors and intentions, in this case, their career decision during the COVID-19 pandemic. As for the relationships between stress, burnout, technology-related issues, and career decision, based on the social cognitive career and motivation theory [14-16], the researcher was able to understand how these elements positively or negatively impacted the career development, career motivation, and career decisions of these groups of participants. Therefore, the application of this theoretical framework was appropriate to answer the research questions.

\section{Materials and Methods}

\subsection{Research Design}

The qualitative phenomenological approach [18] with interpretivism [19] served as the research design in this study. In fact, the human resource shortages and teachers' workforce problems are long-term and ongoing issues, which concern school leadership and government departments internationally. Unlike a qualitative case study, in which the research sites, designs, and participants' groups tend to be limited to a single site or location, the qualitative phenomenological approach tends to collect and gather information and sharing from a wider perspective and population. Therefore, the qualitative phenomeno- 
logical approach was useful to collect a wider perspective from different participants within the country.

\subsection{Recruitment and Participants}

The purposive and snowball sampling strategies were employed [20]. First, the researcher orally invited five former kindergarten teachers who had already left their position during the 2020/2021 academic year in the United States. Once the participants agreed to their participation, the researcher formally sent the invitation letter, consent form, risk statement, protocol, and related materials to the participants.

Once the participants completed the first interview session, they were requested to try their best to refer at least one former kindergarten teacher who had left their teaching position due to the COVID-19 pandemic. After several rounds of referrals and invitations, 60 former kindergarten teachers agreed to join the study.

Please note that 52 participants were married. 50 were married with at least one child whilst none of them were single parents. All had received at least a bachelor's degree, and 21 had received a postgraduate degree. There were 48 female participants. In addition, the participants were required to meet all the following criteria:

- Former kindergarten teacher,

- Left their teaching position due to the COVID-19 pandemic,

- American citizen,

- At least 18 years old and willing to share their stories.

\subsection{Data Collection}

Three data collection tools were used: (1) two sessions of a semi-structured interview; (2) focus group activity; and (3) member checking interview. First, according to Creswell [21], the interview tool is one of the common data collection tools used in qualitative and education studies. According to Seidman [22], in order to collect rich and comprehensive qualitative data for social sciences and education studies, multiple interview sessions are recommended. In fact, lived stories and personal backgrounds cannot be answered in a short period of time. If individuals are given multiple interview sessions, some in-depth understanding and lived stories may be captured. Therefore, the researcher decided to conduct two interview sessions per participant. Based on this protocol and arrangement, the participants were asked to join two virtual-based, semi-structured, oneon-one, and private interview sessions with the researcher. During the interview session(s), the researcher asked the participants about their career decision, stress, and burnout issues of their teaching position. Each interview session lasted from 102 to $119 \mathrm{~min}$.

After all participants completed their interview sessions, the researcher arranged the focus group activities in order to collect stories based on group discussions. Due to the geographic locations and time differences, the focus group activities were also conducted via a virtual-based application. Six participants joined each of the focus group activities, therefore, ten focus group activities were conducted. Each focus group activity lasted from 183 to 201 min with two ten-minute breaks.

After all participants had completed the data collection procedure, the researcher sent the related data to the participants for confirmation. The researcher arranged the member checking interview sessions to confirm the validity of the qualitative data. The member checking interview sessions were conducted via a virtual-based application for 38 to $56 \mathrm{~min}$. All the participants agreed with their supplied data. Please note that all the data collection sessions were recorded by a digital recorder. All the participants agreed with this arrangement.

\subsection{Data Analysis}

After the researcher gathered all the data from the data collection procedure, the researcher transcribed the oral messages and stories to written transcripts for data analysis. The grounded theory approach $[23,24]$ was employed to study the data and conduct the data analysis procedure. The researcher re-read the data several times to categorise the 
connections, themes, and subthemes. First, the researcher employed the open-coding technique to categorise the first-level themes and subthemes [23,24]. At this point, 18 themes and 8 subthemes were merged; however, conducting further analysis was necessary. Therefore, the researcher employed the axial-coding technique to further narrow the data [24]. As a result, three themes and two subthemes were yielded as the second-level themes for this study.

\subsection{Validity}

The idea of triangulation was employed [20] in order to confirm the qualitative data. Multiple interview sessions, focus group activities, and member checking interview sessions were used. With three data collection tools and methods, the researcher could confirm the validity of the data from all the participants. More importantly, based on the member checking interviews, all parties double confirmed their data and stories from the interview sessions and focus group activities. With this confirmation from the triangulation procedure, the researcher could further conduct data analysis.

\subsection{Human Subject Protection}

Privacy is the most important aspect of this study. Therefore, the researcher kept locked and stored the signed consent forms, oral messages, written transcripts, background information, contact information, school information, computer, and related materials in a password-protected cabinet. Only the researcher could read the materials. After the researcher completed the study, all the related information and materials were deleted and destroyed. The current study received support and approval from the Woosong University Academic Research Funding 2021/2022 (D\#2021/211313).

\section{Results and Findings}

Based on the comments of 60 participants in the 120 interview sessions and 10 focus group activities, the researcher captured rich data and categorized themes and subthemes. Table 1 outlines these themes and subthemes.

Table 1. Themes and subthemes.

\begin{tabular}{l} 
Themes and Subthemes \\
\hline 4.1. Personal Considerations: Family and Trained Skills \\
4.1.1. Health Concerns \\
4.2. Surrounding Environment and Individuals: Stress from the School Requirements \\
4.2.1. School Personnel and Administrative Style \\
4.3. Financial Considerations: Overloaded But Low Salary \\
\hline
\end{tabular}

\subsection{Personal Considerations: Family and Trained Skills}

... my family members do not want me to work in the school anymore because it was very dangerous ... the current school facilities and equipment are not ready for the COVID-19 and the infection of the coronavirus ... my family cannot take this risk because we have children and seniors in our household ... (Participant \#33, focus group, married, two children, female, and bachelor).

All 60 participants expressed that their family decisions outweighed their career development in the school environment. The family was one of the most common considerations in their career decisions. Although four of the participants were single individuals with no family responsibilities, all believed they should be responsible to their parents and partner. Due to the lockdown, social distancing recommendations, and health warnings from the local and federal government departments, they had decided to leave the teaching profession. The following is a story from a single individual:

... the government and health professionals told us that many people are sent to the intensive care unit... I don't want my parents and my loved ones ... care 
and cry for my selfishness ... they kept warning me ... I can re-join the teaching one or two years after... and work in other safer companies ... I need to listen and respect my loves ... (Participant \#12, interview, married, one child, female, and bachelor).

Another married participant indicated that his children, wife, parents, and in-laws had encouraged him to work for other professions before the COVID-19 pandemic was over. Although he expressed unwillingness for changing his career development, he believed that health and family considerations outweighed his personal demands, saying:

... yes, I somehow don't want to quit ... but all my family members wanted me to leave for a few years ... I argued with them ... but I think it is good to listen to my wife and children ... I think my children are right ... I always put my children and my wife's recommendation first ... I was a little upset ... but I am happy that I made that decision ... (Participant \#45, interview, married, two children, male, and bachelor).

Many participants felt that their skills and training from their teaching positions strongly prepared them to take on other positions and career pathways even if the economy declined significantly. Although the COVID-19 pandemic and lockdown significantly impacted employment opportunities, all had decided to leave the teaching profession and develop new careers. The researcher captured this story:

... I was in the school for more than a decade ... I worked as an associate department head ... I did not know I could switch to other professions ... but I was wrong ... I am working as a department head of a non-profit organization for immigrants and minority children ... I still need to visit people ... but the risk is lower ... also, I can use my skills from my school and department ... in this organization and position too ... (Participant \#18, interview, single, no children, female, and master).

\section{Health Concerns}

Health concerns are common considerations in career decisions and development [11]. More than 100 health-related keywords were captured from the data collection procedure. Although the government provided some recommendations, such as the use of a facemask for health protection, many did not want to take any risks in the school environment, as many were parents with children at home. Two comments were captured:

... I cannot take any risks ... I might take the virus from the classroom environment back to my home ... one of my sons has a long-term medical problem ... if he gets the virus from me, I don't know how to face my son anymore ... I applied for different positions other than education ... I received more than ten interviews, and I received three offers too ... (Participant \#6, focus group, married, three children, female, and bachelor).

... My children are still very young ... I have already stopped their on-campus classes ... I sent them back home ... but I have to take care of my children and my family ... I really don't want my children ... be outside with other children ... who did not care about their health ... this virus is not easy as I read the news from other channels ... I cannot be sick too ... we could not afford these risks ... (Participant \#8, focus group, married, three children, female, and bachelor).

Another group of participants expressed their concerns about the government and school leadership (i.e., mainly about the health controls and policies). As a result, they left their position and joined other professions. This story was captured:

... perhaps some other teachers could overcome the illness ... but I did not believe the health department and the government ... the virus could impact our lungs ... washing hands ... could not help ... this is common sense ... government urged us ... wash hands ... I don't think this is the way to protect 
my family members and me ... as I care about my sons ... I might just go to another profession and come back later ... (Participant \#40, interview, married, three children, female, and master).

In short, in line with social cognitive career and motivation theory [14-16], the personal considerations of family and health were important to these groups of former kindergarten teachers. With a reflection from a previous study [25], health considerations can be significantly linked to individuals' career decisions. Although turnover and attrition may not be manifest during an economic downfall, skill training and professional development were very important in these groups of former teachers [26].

\subsection{Surrounding Environment and Individuals: Stress from the School Requirements}

Many previous studies [6,27] have indicated that environments and individuals played important roles in teachers' career decisions, particularly regarding their turnover and attrition behavior. The researcher captured two stories reflecting this:

... although the health department asked us to wash hands and wear a mask during the lessons ... the school and classrooms were not safe ... if one student was infected, washing hands could not protect us ... the school asked us to go online for the lessons ... but teachers still needed to go back to school ... what about other teachers or staff ... not all of them wore masks and washed hands ... (Participant \#21, interview, married, one child, female, and bachelor)

... I am afraid ... we have to have body interactions with children ... children need to sing and eat together in the room ... they are not vaccinated and the classroom cannot ensure the social distancing ... in some big classrooms, we may have the social distancing ... but not all teachers can teach in these big classrooms ... children run and play together ... they cannot control themselves with the social distancing ... (Participant \#37, focus group, married, two children, female, and bachelor).

School Personnel and Administrative Style

Almost all participants expressed concern with health protection from their co-workers in the school. Although many reports had indicated that wearing a mask and washing hands could potentially protect their health, not all agreed with the recommendations. A story was captured of these concerns:

... some teachers did not wear masks and cough without any protection ... I was afraid as I believe health is my first consideration ... I have two children, and my own parents are senior citizens ... I cannot take any risks ... if I am infected, who can take care of my family? After careful consideration, I have to take a year off from school... (Participant \#1, interview, married, two children, female, and bachelor).

Another participant with a health background disagreed with the school district's management of health standards and regulations at the school and in the district, particularly over the argument concerning the channels of infection and regulation in the classroom environment:

... the coronavirus is a respiratory tract infection ... washing hands and having fresh air cannot protect us from the infection ... the school told us that we should open the windows and wash our hands ... with basic sense in health ... this is not the ways for respiratory tract protection ... I'm afraid I have to disagree with the regulation and style of the management ... either seek another position in other school districts or so ... I decided to leave the teaching profession for other make-sense workplaces ... (Participant \#26, interview, married, no children, female, and bachelor).

Many participants indicated that although the COVID-19 pandemic was an unexpected health crisis, the people in their surrounding environment did not follow basic 
health regulations and protection. Due to stress around their health and families, they decided to leave their positions and the teaching profession temporarily or indefinitely.

\subsection{Financial Considerations: Overloaded but Low Salary}

A recent study [10] indicated that the economic downturn and the limited financial resources of government agencies had led many school districts to encourage early retirement to balance the budget. However, the workload and responsibilities of teachers were not reduced in line with the financial cut. Moreover, as teachers do not have the same control over students in the virtual-based classrooms as in the physical classroom environment, many teachers indicated that the balance between their extra workload and reduced salary did not match their expectations, particularly in terms of classroom management stress [12]. As a result, more than two-thirds indicated that financial considerations played an important role in their career decisions. This story was captured:

... I can make more money for my family ... my 20 years of experience always helped me up with many good career opportunities and leadership ... the current management in the school district was crazy ... many teachers left their position because of the chaotic styles ... the government did not help, and they were not helpful too ... I am moving to the private sector, and I can see a better future ... (Participant \#60, interview, married, two children, female, and bachelor).

As kindergarten teachers often teach interdisciplinary courses, a proportion of these teachers decided to move to other industries. Two stories were captured:

... I am a private piano trainer ... I am no longer a teacher because I need a break from the financial crisis in the country... I can control my time management and I can do something that I want and love ... I think it is a good move for many of us ... (Participant \#48, focus group, married, one child, female, and bachelor).

... kindergarten teachers cannot make a good salary based on the national statistics ... but if I can do some similar works and tasks with better salary and lower stress ... it is a good move for many of us ... teaching in kindergarten with such a low salary is not fun at all ... the COVID-19 pandemic also makes the school crazy ... the state wants to cut the budget again ... this is not acceptable ... (Participant \#55, interview, married, two children, female, and master).

\section{Discussion}

Based on the social cognitive career and motivation theory [14-16], the current study discovered that family issues and health concerns played an important role(s) in career decisions and motivations, particularly when kindergarten teachers decided to leave their teaching positions and education profession permanently during the COVID-19 pandemic. First of all, a group of parents indicated that they had to balance the advantages and disadvantages within their family. In line with a recent study [28], a group of female professionals needed to leave their position due to overloaded family responsibilities. In this case, many parents decided to give up their career pathways as they had to take care of their children who could not go to school during the COVID-19 pandemic. In line with another recent study [29] it was further echoed that fathers and fathers-to-be needed to balance their financial income (i.e., low salary from the teaching position) and family expenses during the COVID-19 pandemic. With the reflection using the social cognitive career and motivation theory [14-16], many decided to take their trained skills from their previous experiences (i.e., from their teaching experiences) and transfer them to other industries.

Additionally, many participants indicated their concerns about the health policies and safety protections from the school, local, and federal levels. In line with a recent study [30], if organizations and local government departments could not manage their policies effectively, employees were more likely to leave their position due to health and safety issues, such as stress and psychological disorder [31]. In this case, in line with the 
social cognitive career and motivation theory [14-16], health concerns played an important role(s) in their career decisions, particularly for participants with children and senior members in their families. With the reflection of the social cognitive career and motivation theory [14-16], the personal consideration of health concerns played important roles in individuals' career decisions.

Many previous studies [6,27] have indicated that environments and individuals played important roles in teachers' career decisions, particularly in their turnover and attrition behavior. For example, a study [6] indicated that urban school districts and systems have the highest turnover and attrition rates due to their workplace conditions. Many indicated that their school facilities lacked consideration of health crises and global pandemics regarding the school environment. In other words, although teachers wore masks and washed hands during the school day, they could still become infected. Physical and mental stress and concerns continued to impact the career decisions of these groups of participants. In line with social cognitive career and motivation theory [14-16], although the government and school districts tried their best to ensure effective health-related policies and regulations, government actions could not appease the concerns over social distancing and environmental issues, which led to stress and the career decisions of many teachers during the COVID-19 pandemic.

Besides their concerns surrounding environmental factors and student behavior, almost all participants expressed concern regarding their school co-workers and the administrative styles of the leaders, regardless of the COVID-19 pandemic [23,32,33]. Although most teacher encounters are with their students, the behavior of their co-workers and relationships with the school leadership and school district leaders can also influence their physical health, mental stress, and career decisions. In conclusion, in line with social cognitive career and motivation theory [14-16], the behavior of the teachers' co-workers in the school and the managerial style and regulations from the upper management significantly impacted their stress and career decisions during the COVID-19 pandemic [34]. Due to stress around their health and families, they decided to leave their positions and the teaching profession temporarily or indefinitely.

Many participants strongly believed that their skills from their previous school environments had prepared them to take up promotions and upper leadership in other industries and professions [35]. Regardless of the type of school, whether kindergarten or secondary, the skills of classroom management, group control, and time and stress management are essential in many managerial positions. Besides the skill-management relationship, many indicated that private schools and educational organizations had openings as many parents wanted to send their children to these institutions for private tuition. As kindergarten teachers often teach interdisciplinary courses, such as music, mathematics, language, and speaking, a proportion of these teachers decided to switch to the private sector. It should be noted that as these participants are no longer registered as teachers on the state's computer system, they can no longer be categorized as teachers.

In concordance with a recent study [13], the issues of time management, technology, parents, balancing home and teaching, and lack of resources were reflected in the current concerns of these groups of teachers. Another recent study [36] also indicated that early year teachers have transferable interdisciplinary skills that are valued in many private sectors, such as group training and human resources. In line with social cognitive career and motivation theory [14-16], these groups of highly skilled participants tended to work in the private sector due to financial considerations.

\section{Conclusions}

\subsection{Limitations and Future Research Directions}

Four limitations and future research directions were categorised. First, the COVID-19 pandemic is an international health crisis. All parts of the global community face similar teacher shortage issues and financial concerns. As the current study only focused on the situation in the United States, further studies and investigations should be conducted. 
Therefore, future research studies may use this study as the blueprint and direction to collect data from their communities.

Second, due to the limited resources, only one researcher was involved with this study and some people may be concerned about the validity of the study. However, the researcher employed the triangulation tools, including multiple interview sessions, focus group activities, and member checking interview sessions in order to confirm the qualitative data and stories. In the future, researchers may invite multiple researchers and scholars for data collection and data analysis. In this way, different voices and opinions may be collected and merged.

Third, some people may argue that the qualitative research method can create conflicts and biases due to the data collection tools. However, the researcher tried their best to increase the data collection tools (i.e., three tools) in order to exercise triangulation. In the future, researchers may employ a mixed methodology, including surveys and questionnaires at the domestic and international levels for further development.

Fourth, although kindergarten and elementary schools always face human resource shortages, secondary schools and universities also face a similar shortage. Therefore, researchers in secondary school education and higher education administration may also conduct human resource and teacher shortage research studies in order to solve the ongoing problems and situations in the education system.

\subsection{Contributions to the Practice}

Three contributions can be categorised. First, school leadership and department heads may take the results of this study to reform and upgrade their current policies and management in their school environments. In fact, many participants were parents and family breadwinners and although many still needed to make money for their family, the unbalanced and chaotic management at their workplace forced them to leave their position. The school leadership should apply the recommendations from this study to reform their school conditions in order to keep the human resource in their schools.

Second, the government leaders and policymakers should reform the health policy for both public and private school environments. Many participants were concerned about the health and safety issues in their school environments because unlike adults and teenagers, young children could not receive the vaccines due to governmental policies. If a school cannot ensure the social distancing recommendations, other policies and regulations should be introduced in order to meet the needs of all parties (e.g., teachers, parents, and students).

Third, government leaders may take this study as a blueprint to reform and upgrade their human resources and workforce management and planning strategies. Although the COVID-19 pandemic is unique, the human resource and workforce shortage of school teachers will continue after the global crisis. The current situation offers opportunities to rethink and reform the long-term strategies for public and private school planning. The results of this study may provide some recommendations and directions to the Government and Department of Education.

Funding: This research was funded by Woosong University Academic Research Funding 2021.

Institutional Review Board Statement: The study was conducted according to the guidelines of the Declaration of Helsinki, and approved by Woosong University Academic Research Funding 2021/2022 (D\#2021/211313).

Informed Consent Statement: Informed consent was obtained from all subjects involved in the study.

Data Availability Statement: Data available upon request. However, due to the human subject protection, some materials were deleted and destroyed.

Conflicts of Interest: The author declares no conflict of interest. 


\section{References}

1. Stuhmcke, S.M. Children as Change Agents for Sustainability: An Action Research Case Study in a Kindergarten. Ph.D. Thesis, Queensland University of Technology, Brisbane, Australia, 2012.

2. Yang, C.-C.; Fan, C.-W.; Chen, K.-M.; Hsu, S.-C.; Chien, C.-L. As a happy kindergarten teacher: The mediating effect of happiness between role stress and turnover intention. Asia-Pac. Educ. Res. 2018, 27, 431-440. [CrossRef]

3. Klassen, R.; Wilson, E.; Siu, A.F.Y.; Hannok, W.; Wong, M.W.; Wongsri, N.; Sonthisap, P.; Pibulchol, C.; Buranachaitavee, Y.; Jansem, A. Preservice teachers' work stress, self-efficacy, and occupational commitment in four countries. Eur. J. Psychol. Educ. 2013, 28, 1289-1309. [CrossRef]

4. Hancock, C.B. Music Teachers at Risk for Attrition and Migration. J. Res. Music Educ. 2008, 56, 130-144. [CrossRef]

5. Teacher Turnover: What You Need to Know. Available online: https://content.acsa.org/articles/teacher-turnover-what-youneed-to-know (accessed on 30 July 2021).

6. Weiner, L. The Future of Our Schools: Teachers Unions and Social Justice; Haymarket Books: Chicago, IL, USA, 2012.

7. Retta, M. Teachers are quitting their jobs over stress of COVID, overwork. Teen Vogue, 10 August 2021.

8. Pressley, T. Factors contributing to teacher burnout during COVID-19. Educ. Res. 2021, 50, 325-327. [CrossRef]

9. Jagannathan, M. Teachers Were Already Leaving the Profession due to Stress: Then COVID-19 Hit. Mark. Watch 2021. Available online: https: / /www.marketwatch.com/story/teachers-were-already-leaving-the-profession-due-to-stress-then-covid-19-hit11614025213 (accessed on 1 April 2021).

10. Diliberti, M.K.; Schwartz, H.L.; Grant, D. Stress Topped the Reasons Why Public School Teachers Quit, Even Before COVID-19; RAND Corporation: Santa Monica, CA, USA, 2021.

11. McDermott, R.J. When US and state governments go viral: In-person reopening of schools during the COVID-19 Pandemic and then what?-A commentary. Health Behav. Policy Rev. 2020, 7, 366-373. [CrossRef]

12. MacIntyre, P.D.; Gregersen, T.; Mercer, S. Language teachers' coping strategies during the Covid-19 conversion to online teaching: Correlations with stress, wellbeing and negative emotions. System 2020, 94, 102352. [CrossRef]

13. Sokal, L.J.; Trudel, L.G.E.; Babb, J.C. Supporting teachers in times of change: The job demands- resources model and teacher burnout during the COVID-19 pandemic. Int. J. Contemp. Educ. 2020, 3, 67. [CrossRef]

14. Dos Santos, L. Developing bilingualism in nursing students: Learning foreign languages beyond the nursing curriculum. Healthcare 2021, 9, 326. [CrossRef]

15. Dos Santos, L. Motivations and career decisions in occupational therapy course: A qualitative inquiry of Asia-Pacific international students in Australia. Adv. Med. Educ. Pract. 2021, 12, 825-834. [CrossRef]

16. Lent, R.W.; Brown, S.D.; Hackett, G. Toward a unifying social cognitive theory of career and academic interest, choice, and performance. J. Vocat. Behav. 1994, 45, 79-122. [CrossRef]

17. Bandura, A. Social Foundations of Thought and Action: A Social Cognitive Theory; Prentice-Hall: Englewood Cliffs, NJ, USA, 1986.

18. Giorgi, A. Phenomenology and Psychological Research; Duquesne University Press: Pittsburgh, PA, USA, 1985.

19. Burrell, G.; Morgan, G. Sociological Paradigms and Organisational Analysis: Elements of the Sociology of Corporate Life; Heinemann: London, UK, 1979.

20. Merriam, S.B. Qualitative Research: A Guide to Design and Implementation; Jossey Bass: San Francisco, CA, USA, 2009.

21. Creswell, J. Qualitative Inquiry and Research Design: Choosing among Five Approaches; Sage: Thousand Oaks, CA, USA, 2012.

22. Seidman, I. Interviewing as Qualitative Research: A Guide for Researchers in Education and the Social Sciences, 4th ed.; Teachers College Press: New York, NY, USA, 2013.

23. Kwee, C.T.T. I want to teach sustainable development in my English classroom: A case study of incorporating sustainable development goals in English teaching. Sustainability 2021, 13, 4195. [CrossRef]

24. Strauss, A.; Corbin, J.M. Basics of Qualitative Research: Grounded Theory Procedures and Techniques; Sage: Thousand Oaks, CA, USA, 1990.

25. Wu, W.; Rafiq, M.; Chin, T. Employee well-being and turnover intention. Career Dev. Int. 2017, 22, 797-815. [CrossRef]

26. Grissom, J.; Viano, S.; Selin, J. Understanding employee turnover in the public sector: Insights from research on teacher mobility. Public Adm. Rev. 2016, 76, 241-251. [CrossRef]

27. Weiner, L.; Jerome, D. Urban Teaching: The Essentials, 3rd ed.; Teachers College Press: New York, NY, USA, 2016.

28. Juengst, S.B.; Royston, A.; Huang, I.; Wright, B. Family leave and return-to-work experiences of physician mothers. JAMA Netw. Open 2019, 2, e1913054. [CrossRef]

29. Harrington, B. The new dad: The career-caregiving conundrum. In Engaged Fatherhood for Men, Families and Gender Equality; Grau, M., Maestro, M., Bowles, H., Eds.; Springer: Cham, Switzerland, 2022; pp. 197-212.

30. Demirović Bajrami, D.; Terzić, A.; Petrović, M.D.; Radovanović, M.; Tretiakova, T.N.; Hadoud, A. Will we have the same employees in hospitality after all? The impact of COVID-19 on employees' work attitudes and turnover intentions. Int. J. Hosp. Manag. 2021, 94, 102754. [CrossRef]

31. Labrague, L.J.; Santos, J.A.A. Fear of COVID-19, psychological distress, work satisfaction and turnover intention among frontline nurses. J. Nurs. Manag. 2021, 29, 395-403. [CrossRef] [PubMed]

32. Kwee, C. The application of career theories in teachers' professional development and career decision: A literature review. Univers. J. Educ. Res. 2020, 8, 3997-4008. [CrossRef] 
33. Hallinger, P.; Heck, R.H. Collaborative leadership and school improvement: Understanding the impact on school capacity and student learning. Sch. Leadersh. Manag. 2010, 30, 95-110. [CrossRef]

34. Daniel, S.J. Education and the COVID-19 pandemic. Prospects 2020, 49, 91-96. [CrossRef] [PubMed]

35. Burdina, G.M.; Krapotkina, I.E.; Nasyrova, L.G. Distance learning in elementary school classrooms: An emerging framework for contemporary practice. Int. J. Instr. 2019, 12, 1-16. [CrossRef]

36. Ardhian, T.; Ummah, I.; Anafiah, S.; Rachmadtullah, R. Reading and critical thinking techniques on understanding reading skills for early grade students in elementary school. Int. J. Instr. 2020, 13, 107-118. [CrossRef] 